\title{
PHYSIOLOGICAL SEEDS QUALITY: SPATIAL DISTRIBUTION AND VARIABILITY AMONG SOYBEAN PLANT POPULATION
}

\author{
QUALIDADE FISIOLÓGICA DE SEMENTES: DISTRIBUIÇÃO ESPACIAL E \\ VARIABLIDADE ENTRE POPULAÇÕES DE PLANTAS DE SOJA
}

\author{
Leandro Damero CANTARELLI ${ }^{1}$; Luis Osmar Braga SCHUCH'; \\ Cassyo de Araujo RUFINO ${ }^{3}$; Lizandro Ciciliano TAVARES ${ }^{3}$; \\ Jucilayne Fernandes VIEIRA ${ }^{3}$
}

1. Engenheiro Agrônomo, Msc em Ciência e Tecnologia de Sementes, Universidade Federal de Pelotas UFPel, Pelotas, RS, Brasil; 2. Professor Adjunto, Programa de Pós Graduação em Ciência e Tecnologia de Sementes, Pelotas, RS, Brasil; 3. Doutorandos em Ciência e Tecnologia de Sementes - UFPel, Pelotas, Pelotas, RS, Brasil.cassyo.araujo@yahoo.com.br

\begin{abstract}
The study aimed to evaluate the influence of physiological seed quality on the spatial distribution of plants in the field, as well as the effect on variability among soybean plants. Six lots of soybean cultivar CD 202, with three vigor levels (high, medium and low) and two lots on each level were used. Lots of high physiological quality showed germination of $96 \%$ and lots considered of medium vigor showed $82 \%$ of germination and vigor between $60 \%$ and $67 \%$, whereas lots of low vigor showed $70 \%$ germination and vigor between $55 \%$ and $58 \%$. The test was conducted in plots formed by seven $5 \mathrm{~m}$ long rows with spacing of $0.45 \mathrm{~m}$. The sowing was performed by opening furrows by hand with the equidistant distribution of seeds using marked rulers, corrected by the germination of each seed lot. Lots of seeds of higher vigor provide greater uniformity in the distribution of plants in the field. The reduction in seed physiological quality provides increased variability among plants within populations, throughout the entire developmental period of soybean, also affecting the seed yield per plant.
\end{abstract}

KEYWORDS: Glycine max (L.) Merrill. Sowing failures. Differences between plants. Seed vigor.

\section{INTRODUCTION}

Soybean (Glycine $\max$ (L.) Merrill) has great importance in Brazil and increases in the productivity and production of this crop are recorded each year. It is a crop with greater economic relevance in the country, and in 2013/2014 occupied an area of 29.4 million hectares, with an average yield of $3100 \mathrm{~kg} \mathrm{ha}^{-1}$ (CONAB, 2013).

In this context, in the crop implementation, it is essential to use high quality seeds to achieve high performance results. With regard to its role in human history and in the agricultural chain, seeds are presented as an indispensable input, playing an important role for quantitative and qualitative increases in productivity. Therefore, the use of high quality seeds is important for the success of any crop (GASPAR; NAKAGAWA, 2002). It depends on the use of seeds with the ability to germinate rapidly and uniformly, since problems in seedling emergence may impair the performance of plants (MARCOS FILHO, 2005). According to Hampton (2002), seed vigor exerts profound influence on the initial population establishment and development of plants, which can affect plant production. In physiological seed quality, represented by seed germination and vigor, it is important to highlight the effect of vigor on plant performance and plant regeneration. Seeds with high physiological quality have higher metabolic rates, enabling faster and more uniform primary root formation in the process of germination, higher growth rates and the production of seedlings with larger initial size (SCHUCH et al., 1999).

The yield potential of soybean is genetically determined; in other words, the plant itself carries its productive potential and how this potential will be achieved in agriculture depends on the effect of limiting factors that act during the crop cycle. The effect of these factors can be minimized by adopting a set of management practices, which allows the plant community to use environmental resources in the best possible way (HEIFFIG et al., 2006). Therefore, appropriate populations of plants are a factor as well as the perfect arrangement of soybean plants, which has an influence on growth, the insertion of pods, and the number of branches and pods (GAUDÊNCIO et al., 1990). The combination of plant density and row spacing defines the crop plant population, which influences some agronomic characteristics of soybean plants (URBEN FILHO; SOUZA, 1993), and can modify grain production (LAM SANCHEZ; VELOSO, 1974). 
In soybean, Vanzolini and Carvalho (2002) also found that the most vigorous seeds produced a long primary root, and greater root length and better development of the seedlings. The first soybean plants that emerged always achieved an advantage over plants that emerged subsequently on alternate positions along the same row (EGLI, 1993). This superiority was reflected in higher yield per plant, as noted by Nafziger et al. (1991), who reported an increase in the proportion of plants that emerged early in the canopy, and a reduced yield of plants that emerged later.

As reported by Rambo et al. (2003), several studies have evaluated competition between plants and their yield, depending on the arrangement population. These authors also verified that the greatest competition occurs between plants in the same row; therefore, the distribution of seeds in the soil becomes a key element.

Yields derived by modifying the arrangement of plants are due morphophysiological changes, which may be best understood by the analysis of yield components and plant morphology. In a study performed by Board et al. (1990), it was observed that for the same population of plants, reducing the spacing soybean increases the number and length of the branch. In this situation the dry mass is reduced, as is the relative leaf area and leaf/branches. Furthermore, some indices are usually modified, such as leaf area ratio and specific leaf area, which help in describing the behavior of plants under competition. All of the stress experienced by the crop tends to be reflected in the morphophysiological plant changes, with a direct impact on productivity (LAMEGO et al., 2005).

The ideal density of plants for each cultivar depends mainly on cultivar characteristics, such as life cycle, plant height, growth habit, laying index and juvenile period (GILIOLI et al., 1984). These agronomic traits are influenced by spacing and planting density, as demonstrated in several studies (URBEN FILHO; SOUZA, 1993). However, according to Endres (1996), the accumulation of plants in some parts of the crop may cause evolution of higher plants, which are less branched, with smaller individual production and reduced stem diameter, therefore making them more prone to lodging. However, void spaces left in the line enables the establishment of soybean plants with reduced size, and also facilitates the development of weeds. Plant stands produced in this way can show reduced productivity and difficulties during mechanical harvesting.

Schuch and Peske (2008) reported that, in highly productive crops, plants are subjected to a high degree of competition. For these authors, failures of plants that occur in crops can be caused by low quality seeds, as well as due to the sowing process, i.e. the seed was not deposited in the location for which it was destined. On the other hand, deposition of two seeds in the same place can also occur, resulting in so-called double plants, which increases competition between them, resulting in reduced production.

It has been speculated that the use of lowquality seeds would provide non-uniform spatial distribution of the plants along the sowing row, which could cause damage due to intraspecific competition within the population of plants. In studies conducted by Cantarelli et al. (2004), this kind of behavior was observed in an oat crop. Several studies have demonstrated competitive differences between plants within plant communities, where more developed plants provided an advantage in intraspecific competition.

This study aimed to evaluate the influence of physiological seed quality on the spatial distribution of plants in the field, as well as the effect on variability among plants within populations of soybean.

\section{MATERIAL AND METHODS}

The experiment was conducted in the municipality of Capão do Leão-RS, at the experimental area of the Department of Plant Science, of the Faculty of Agronomy "Eliseu Maciel" from Federal University of Pelotas (FAEM/UFPel).

The soil from experimental area was classified as a Planosol belonging to the mapping unit Pelotas. Soil samples were collected and sent for chemical analysis to the Laboratory of Soils Analysis of the FAEM/UFPel. The results obtained were as follows: clay 16\%; organic matter: $2.59 \%$; pH in water: 5.3 ; $\mathrm{Al} 3+$ : $0.4 \mathrm{me} / 100 \mathrm{ml}$; SMP index: 6.0 (SHOEMAKER, MCLEAN; PRATT, 1961); $\mathrm{Na}: 20$ ppm; Ca2+: $2.4 \mathrm{me} / 100 \mathrm{ml} ; \mathrm{Mg} 2+: \mathrm{me} / 100 \mathrm{ml}$ 0.9, P: $13.5 \mathrm{ppm}, \mathrm{K}: 36 \mathrm{ppm}$. Plant fertilization was performed according to the recommendations of the COMMITTEE ON SOIL FERTILITY - RS/SC (2004).

Soybean sowing was carried out with the cultivar CD 202 using the tillage system on black oat. The seeds were inoculated with Brandyhizobium japonicum in the proportion of 150 $\mathrm{mL}$ of inoculum to every $50 \mathrm{~kg}$ of seeds. The seeds were not treated with fungicides and insecticides because of manual manipulation at the time of sowing. Cover crop desiccation was performed with 
the total herbicide application (Roundup) at a dose of 3.0 L.ha ${ }^{-1}$.

The experiment was conducted in the experimental randomized blocks design with four replications. The treatments consisted of 3 levels of soybean seed physiological quality. For each treatment, two seed lots with high physiological quality, two lots with medium vigor and two lots of low vigor were used, totaling six different seed lots. Seed germination and seed vigor were determined by the accelerated aging test; results for each of the different lots are presented in Table 1. Seed lots of high and medium vigor came from soybean producers, while lots of low physiological qualities were obtained by artificially accelerating the aging of high quality seed lots. Periods of time and temperature were preliminarily determined to achieve the desired levels of vigor; for one of the lots of high physiological quality, a combination of $45^{\circ} \mathrm{C}$ for $48 \mathrm{~h}$ was used and for the other, this was $41^{\circ} \mathrm{C}$ for $72 \mathrm{~h}$.

Table 1. Values of seed germination and seed vigor, determined by the accelerated aging test, for different lots classified as high, medium and low vigor. Capão do Leão, RS.

\begin{tabular}{|c|c|c|c|c|c|c|}
\hline \multirow{3}{*}{ Quality Parameters } & \multicolumn{6}{|c|}{ Physiological quality/Lots } \\
\hline & \multicolumn{2}{|c|}{----High---- } & \multicolumn{2}{|c|}{----Medium---- } & \multicolumn{2}{|c|}{----Low---- } \\
\hline & A & $\mathrm{B}$ & $\mathrm{C}$ & $\mathrm{D}$ & $\mathrm{E}$ & $\mathrm{F}$ \\
\hline Germination $(\%)$ & 96 & 96 & 82 & 82 & 70 & 70 \\
\hline Vigor $(\%)$ & 96 & 95 & 60 & 67 & 55 & 58 \\
\hline
\end{tabular}

The trial was conducted in plots consisting of 7 rows of $5 \mathrm{~m}$ length totaling 35 linear meters per plot. The rows were spaced $0.45 \mathrm{~m}$ apart. The sowing (24th November) was done with equidistant distribution of seeds along the lines to obtain a plant population of 300,000 plants $\mathrm{ha}^{-1}$. Due to the differences in physiological seed quality and the number of seeds being corrected per meter depending on the germination of the different lots, plots were seeded using 3 different distances. For lots of high physiological quality, a distance of 7.1 $\mathrm{cm}$ was used between seeds in the row, while, for lots of medium and low vigor, the seeds were spaced $6.1 \mathrm{~cm}$ and $5.2 \mathrm{~cm}$ apart, respectively. The spatial distribution of the plants was determined by the number of points of the sowing that failed to establish plants along the row. Thereby, 20 days after sowing, the number of consecutive failures of $1,2,3,4,5$ and 6 sowing points that failed to establish plants were counted along the entire length of each plot.

At 40 days after emergence, all plants present in a $4 \mathrm{~m}$ long row were collected from each plot, to determine plant height, leaf area and dry biomass of plants. At physiological maturity, all plants present in two 4 meter long rows were collected for the determination of plant height, stem diameter, number of stems per plant, number of pods per plant, and yield seeds per plant. In both sampling times, the plants were evaluated individually for each of the parameters. The plant height was determined using a graduated scale, whereas stem diameter was determined on the basis of measuring plants with a caliper. The leaf area was determined using a photoelectric determiner Li-
COR Model Li-3100, while determining dry weight was performed using the drying method at $65^{\circ} \mathrm{C}$ until a constant weight was reached. Pods were counted and then threshing was performed manually, before grain yield was determined for each plant. Determination of grain moisture of the samples was performed, which was corrected to $13 \%$.

Mean values and coefficients of variation for each parameter within each plot were calculated. The coefficient of variation was used as an indicator of plant variability within populations. This criterion considers that a higher coefficient of variation indicates greater variability among the plant populations. For controlling weeds post-emergence, the following commercial products were used: Fusilade ${ }^{\circledR}$ at a dose of 1.5 L.ha $^{-1}$, for controlling weeds of narrow leaves, and Flex ${ }^{\circledR}$ at a dose of 0.8 L.ha ${ }^{-1}$, for controlling weeds with large leaves; these applications were made 15 days after emergence. The insect control was performed with two applications of the insecticide Azodrin $₫ 400$ at a dose of 0.75 L.ha $^{-1}$. The late season diseases were controlled in a single application of the fungicide Folicur 200® at a dose of 0.75 L.ha $^{-1}$. The applications of chemicals were performed using a backpack sprayer cone nozzle, with a spray volume of 200 L.ha $^{-1}$.

Statistical analysis was performed using the statistical program SANEST (ZONTA et al., 1986). The experimental data, including variation coefficients, obtained in each experimental unit were subjected to analysis of variance, and the effects of treatment were assessed by $\mathrm{F}$ test. For 
comparison of means test, the Duncan test was used at a level of $5 \%$ probability.

\section{RESULTS AND DISCUSSION}

Figure 1 shows the spatial distribution of the plants along the row of sowing, represented by the number of failures of plant establishment in $1,2,3$, 4, 5 and 6 consecutive points of sowing, along a 35 meter long line, depending on the physiological quality of the soybean seeds. It can be observed that
CATARELLI, L. D. et al.

the number of failures of a single point of sowing was relatively high and similar between the three levels of seed physiological quality. As the number of consecutive failures of sowing points increased, there was a trend to reduce the occurrence of this problem. However, in seed lots with low physiological quality, the number of consecutive failures was higher than in seed lots with high quality, while seed lots with medium vigor score were located in an intermediate position.

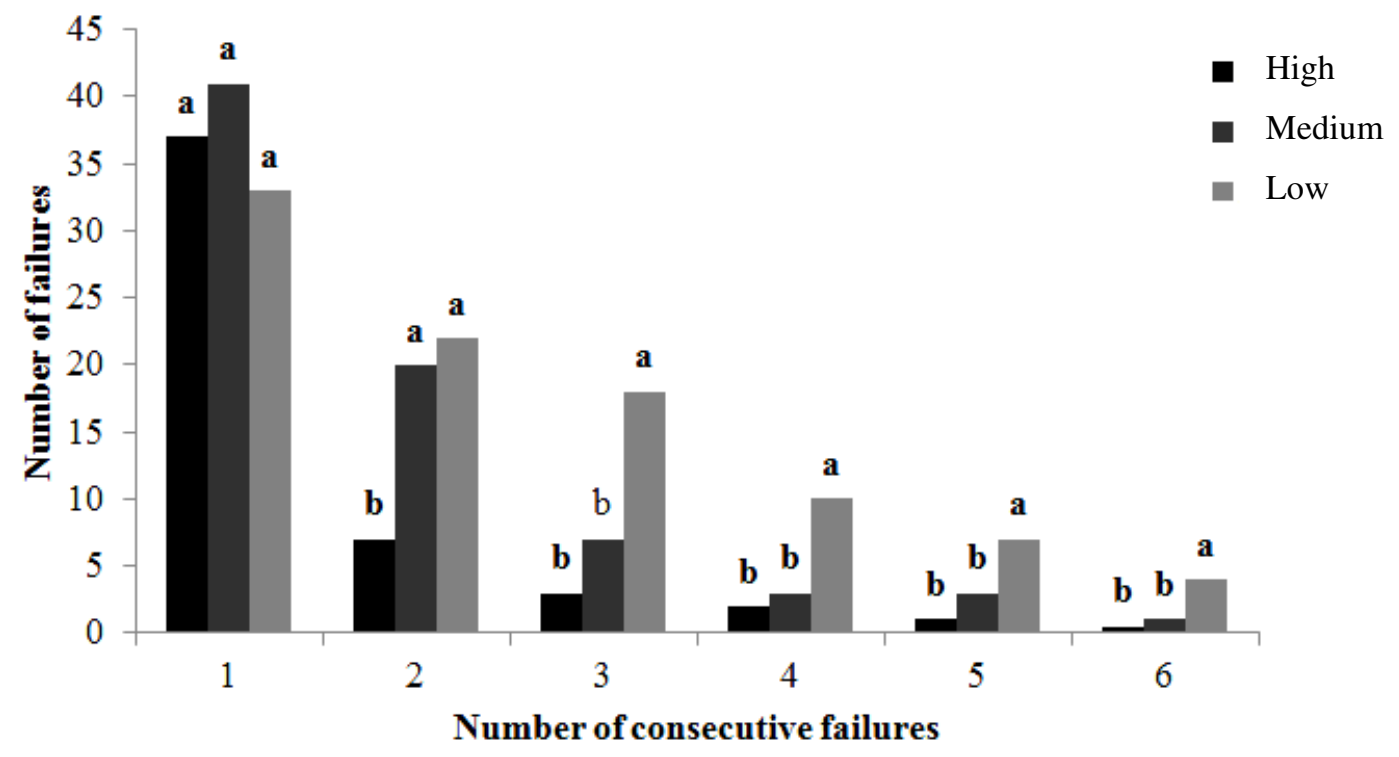

Figure 1. Spatial distribution of soybean along the seeding line, depending on the physiological quality of the seed lots.

Also, in lots of high physiological quality, around eight failures of two consecutive points of sowing occurred, and around 23 failures were seen for lots of low vigor, in a 35 meter line. For failures of three and four consecutive points of sowing, the lots of low vigor exhibited about 19 and 10 occurrences, while high quality seed lots showed four and two occurrences. Lots of high physiological quality showed failures of five and six consecutive points of sowing, whereas lots of low physiological quality also showed around four and seven occurrences, respectively. Cantarelli et al. (2004) worked with oat seeds and found a similar behavior.

The occurrence of consecutive failures was markedly increased in lots of low vigor, as the number of consecutive plants failing increased, as also observed by Cantarelli et al. (2004), while there was no difference in the number of occurrences of plant failures between different levels of vigor. Around three times more consecutive failures of two plants were observed, along with five times more failures for three and four consecutive plants and twenty four times more failures for five and six consecutive plants in lots of low physiological quality compared to lots of high physiological quality.

Considering the number of consecutive sowing points showing failure of plant establishment, and considering that the sowing points were located at a distance of $7.1 \mathrm{~cm}, 6.1 \mathrm{~cm}$ and $5.2 \mathrm{~cm}$ for high, medium and low physiological levels, it was found that lots of low quality showed about 37 spaces of $10.4 \mathrm{~cm}$ without plants, 23 spaces of $15.6 \mathrm{~cm}, 19$ spaces of $20.8 \mathrm{~cm}, 10$ spaces of $26 \mathrm{~cm}, 7$ spaces of $31.2 \mathrm{~cm}$ and 4 spaces of 36.4 $\mathrm{cm}$ over a $35 \mathrm{~m}$ sowing row. However, lots of high vigor exhibited about 37 spaces of $14.2 \mathrm{~cm}$ without plants, eight spaces of $21.3 \mathrm{~cm}$, four spaces of 28.4 $\mathrm{cm}$, two spaces of $35.5 \mathrm{~cm}, 0.5$ spaces of $42.6 \mathrm{~cm}$ and $0.2 \mathrm{~cm}$ spaces of 49.7 in the same 35 meter line.

Thereby, it appears that seed lot quality affected the spatial distribution of plants within the soybean plant community. High physiological seed 
lots provided high quality spatial distribution that was more uniform within the plants community, while lots of low physiological quality promoted the uneven spatial distribution of plants and high plant grouping at places where there were no failures, since, to compensate for lower seed germination, the seeds were placed nearest to each other along the sowing line with distances between seeds of $7.1 \mathrm{~cm}$, $6.1 \mathrm{~cm}$ and $5.2 \mathrm{~cm}$, respectively, for lots of high, medium and low quality. Therefore, the practice of correcting the sowing density using the values of germination or vigor of the seed lots can be useful in establishing a proper plant population or closer than desired. However, the spatial distribution of plants in the community will be compromised. The results obtained by Daynard and Muldon (1983), when evaluating morphological characteristics and grain yield under conditions of uniform sowing, showed greater variability as the plant population increased.
Therefore, in crops with high plant populations, greater care must be taken with the factors that cause uneven emergence because there is a greater possibility of losses in grain yield (MERROTO JUNIOR et al., 1999).

In Table 2, the values of the coefficient of variation for the variables plant height, leaf area and dry matter at 40 days after emergence (40 DAE) are listed. The effects of the use of seeds with high physiological quality are noticeable, and all variables presented with the smallest $\mathrm{CV}$ (coefficient of variation) showing lower variability of plants in the same population, reaching differences of up to $48 \%$ compared with populations with low seed physiological quality. However, for the levels of medium and low vigor, higher $\mathrm{CV}$ was observed, indicating that the lowest seed physiological quality in a plant population provides the highest variability of plants.

Table 2. Plant variability within populations of soybean depending on physiological seed quality as assessed by the coefficient of variation $(\mathrm{CV})$, plant height $(\mathrm{cm})$, leaf area $\left(\mathrm{cm}^{-2}\right)$ and dry plants biomass $(\mathrm{g})$, evaluated at 40 (DAE) days after emergence.

Components of de plants variability at 40 DAE

\begin{tabular}{cccc}
\hline \multirow{2}{*}{ Physiological Quality } & Height of plants $(\mathrm{cm})$ & Leaf area $\left(\mathrm{cm}^{-2}\right)$ & Dry plants biomass $(\mathrm{g})$ \\
\cline { 2 - 4 } & $\mathrm{CV}(\%)$ & $\mathrm{CV}(\%)$ & $\mathrm{CV}(\%)$ \\
\hline High & $11.91 \mathrm{a}$ & $37.12 \mathrm{a}$ & $29.66 \mathrm{a}$ \\
Medium & $14.78 \mathrm{a}$ & $48.12 \mathrm{~b}$ & $48.08 \mathrm{~b}$ \\
Low & $20.13 \mathrm{~b}$ & $60.62 \mathrm{~b}$ & $58.93 \mathrm{~b}$ \\
\hline Average & 15.61 & 48.62 & 42.35 \\
\hline CV $(\%)$ & 19.41 & 26.71 & 13.6 \\
\hline
\end{tabular}

* Means followed by the same letter do not differ by Duncan test at 5\% significance. CV: Coefficient of variation.

At harvest time, variability among populations of plants is not observed for plant height as a function of physiological seed quality (Table 3 ). However, for stem diameter, it was found that medium and low physiological quality showed greater variability among plants and it may also be noted that when there was decrease in plant vigor, it was possible to observe an increase in morphological differences of soybean plants; also, seeds of high physiological quality developed into plants with less variability.

Table 3. Plant variability within populations of soybean depending on physiological seed quality as measured by the coefficient of variation $(\mathrm{CV})$ for plant height $(\mathrm{cm})$, number of stems per plant, number of pods per plant and seed yield per plant $(\mathrm{g})$, evaluated at harvest.

Components of plants' variability

\begin{tabular}{|c|c|c|c|c|c|}
\hline \multirow{2}{*}{$\begin{array}{l}\text { Physiological } \\
\text { quality }\end{array}$} & $\begin{array}{l}\text { Plant height } \\
\quad(\mathrm{cm})\end{array}$ & $\begin{array}{l}\text { Stem diameter } \\
(\mathrm{cm})\end{array}$ & $\begin{array}{c}\text { Number of hastes } \\
\text { per plant }\end{array}$ & $\begin{array}{l}\text { Number of } \\
\text { pods per plant }\end{array}$ & $\begin{array}{l}\text { Seed yields per } \\
\text { plant }(\mathrm{g})\end{array}$ \\
\hline & CV $(\%)$ & $\mathrm{CV}(\%)$ & CV $(\%)$ & $\mathrm{CV}(\%)$ & CV $(\%)$ \\
\hline High & $12.61 \mathrm{a}$ & $17.35 \mathrm{~b}$ & $35.06 \mathrm{a}$ & $39.20 \mathrm{a}$ & $45.73 \mathrm{a}$ \\
\hline Medium & $13.94 \mathrm{a}$ & $24.45 \mathrm{a}$ & $48.83 \mathrm{~b}$ & $47.89 \mathrm{~b}$ & $48.45 \mathrm{ab}$ \\
\hline Low & $15.16 \mathrm{a}$ & $22.86 \mathrm{a}$ & $46.17 \mathrm{~b}$ & $52.64 \mathrm{~b}$ & $61.94 \mathrm{~b}$ \\
\hline
\end{tabular}




\begin{tabular}{|c|c|c|c|c|c|}
\hline Average & 21.88 & 27.75 & 41.14 & 43.02 & 46.19 \\
\hline $\mathrm{CV}(\%)$ & 19.38 & 7.87 & 13.65 & 9.93 & 17.34 \\
\hline
\end{tabular}

* Means followed by the same letter do not differ by Duncan test at 5\% significance. CV: Coefficient of variation.

The number of stems per plant was a sensitive variable to identify differences between levels of physiological seed quality and can demonstrate that high quality seeds developed more uniform plants within plots. The opposite occurred with plants originating from seeds with low and medium vigor, which showed greater variability among plant components. Therefore, a similar behavior was observed in the variables number of pods per plant and seed yield per plant, which tended to show increased variability among plants within populations, and there was a reduced level of physiological seed quality.

According to RESENDE et al. (2004), in studies with different populations of plants, the increase in density significantly altered yield. The increase in productivity with increasing spacing was also verified by PEIXOTO et al. (2000), who concluded that, regardless of density, the cultivars presented a trend towards grain yield compensation, but this was limited.

\section{CONCLUSIONS}

Lots of seeds with higher physiological quality provide greater uniformity in the distribution of plants in the field.

The reduction in seed physiological quality provides increased variability among plants within populations, throughout the period of the development of soybean, and also affecting seed yield per plant.

\section{REFERENCES}

BOARD, J. E.; HARVILLE, B. G.; SAXTON, A. M. Narrow row seed yield enhancement indeterminate soybean. Agronomy Journal, Madison, v. 82, n. 1, p. 64-68, 1990.

CANTARELLI, L. D.; SCHUCH, L. O. B.; SCHIAVON, R.; PICOLI, V. A.; MACHADO, R. F. Distribuição espacial de plantas de aveia branca (Avena sativa $L$.), em função do vigor e da classificação de sementes. In: XIX SEMINARIO PANAMERICANO DE SEMILLAS, 2004, ASSUNÇÃO. CONFERENCIAS Y RESUMENES DE TRABAJOS PRESENTADOS. 2004. v. 1, p. 291-291.

COMPANHIA NACIONAL DE ABASTECIMENTO. Acompanhamento de safra brasileira: grãos, sexto levantamento, março 2014. Brasília: Conab, 2014, 22 p. Disponível em:<http://www.conab.gov.br/conabweb/download/safra/4graos_12.03.14.pdf>. Acesso em: 23 de abril de 2014.

DAYNARD, T. B., MULDON, J. F. Plant-to-plant variability of maize plants growth at different densities. Canadian Journal of Plant Science, v. 63, p. 45-59, 1983. http://dx.doi.org/10.4141/cjps83-005

EGLI, D. B. Relationship of uniformity of soybean seedling emergence to yield. Journal of Seed Technology, East Leasing, v. 17, n. 1, p. 22-28, 1993.

ENDRES, V. C. Espaçamento, densidade e época de semeadura. In: EMBRAPA. Centro de Pesquisa Agropecuária do Oeste (Dourados, MS). Soja: recomendações técnicas para Mato Grosso do Sul e Mato Grosso. Dourados, 1996, p. 82-85. (Circular Técnica, 3).

GASPAR, C. M.; NAKAGAWA, J. Teste de condutividade elétrica em função do número de sementes e da quantidade de água para sementes de milheto. Revista Brasileira de Sementes, Brasília, v. 24, n. 2, p. 70-76, 2002. http://dx.doi.org/10.1590/S0101-31222002000100012

GAUDÊNCIO, C. A. A.; GAZZIERO, D. L. P.; JASTER, F.; GARCIA, A.; WOBETO, C. População de plantas de soja no sistema de semeadura direta para o Centro-Sul do Estado do Paraná. Londrina: Embrapa, CNPSo, 1990. 4p. (Comunicado Técnico, 47). 
GILIOLI, J. L.; SEDIYAMA, T.; FONSECA JR., N. S. Herança do número de dias para floração em quatro mutantes naturais em soja estudada sob condições de dias curtos. In: III SEMINÁRIO NACIONAL DE PESQUISA DE SOJA. Anais... Campinas. Londrina, EMBRAPA-CNPSo. 1984, p.47.

HAMPTON, J. G. What is seed quality? Seed Science and Technology, Zürich, v.30, n.1, p.1-10, 2002.

HEIFFIG, L. S.; CÂMARA, G. M. S.; MARQUES, L. A.; PEDROSO, D. B.; PIEDADE, S. M. S.

Fechamento e índice de área foliar da cultura da soja em diferentes arranjos espaciais. Campinas, 2006.

LAMEGO, F. P.; FLECK, N. G.; BIANCHI, M. A.; SCHAEDLER, C. E. Tolerância a interferência de plantas competidoras e habilidade de supressão por cultivares de soja - I. Resposta de variáveis de crescimento. Planta Daninha, Viçosa, v. 23, n. 3, p. 405-414, 2005.

LAM-SANCHEZ, A.; VELOSO, E. J. Efeito do espaçamento e da densidade de plantio, sobre várias características agronômicas na cultura da soja (Glycine max (L.) Merrill), variedade "Viçoja" em Jaboticabal, SP. Científica, São Paulo, v. 2, n. 2, p. 137-148, 1974.

NAFZIGER, E. D., CARTER, P. R., GRAHAM. E. E. Response of corn to uneven emergence. Crop Science, Madison, v. 31, p. 811-815, 1991. http://dx.doi.org/10.2135/cropsci1991.0011183X003100030053x

MEROTTO JUNIOR, A.; SANGOI, L.; ENDER, M.; GUIDOLIN, A. F.; HAVERROTH, H. S. A desuniformidade de emergência reduz o rendimento de grãos de milho. Ciência. Rural. v. 29, n. 4, pp. 595601. 1999. http://dx.doi.org/10.1590/S0103-84781999000400004

MARCOS FILHO, J. Fisiologia de sementes de plantas cultivadas. Piracicaba: Fealq, 2005. 495p.

MONTEIRO, C. de A. Análise de crescimento e produtividade agrícola de girassol conduzido na safrinha em cinco densidades de plantas. 2001. 94f. Dissertação (Mestrado em Agronomia) - Universidade do Estado de São Paulo.

PEIXOTO, C. P.; CÂMARA, G. M. S.; MARTINS, M. C; MARCHIORI, L. F. S. M.; GUERZONI, R. A. MATTIAZZI. Época de semeadura e densidade de plantas de soja: I. componentes da produção e rendimento de grãos. Scientia Agrícola. Piracicaba, v. 57, n. 1, p. 89-96, jan/mar, 2000.

RAMBO, L.; COSTA, J. A.; PIRES, J. L. F.; PARCIANELLO, G.; FERREIRA, F. Rendimento dos grãos de soja em função do arranjo de plantas. Ciência Rural. Santa Maria, v. 33, n. 3, p. 405-411, 2003.

http://dx.doi.org/10.1590/S0103-84782003000300003

REZENDE, P. M.; GRISC, F, GOMES, L. L.; TOURINO, M. C. C.; BOTREL, E. P. Efeito da semeadura a lanço e da população de plantas no rendimento de grãos e outras características da soja [Glycine max (L.) Merrill]. Ciências Agrotécnicas, v. 28, p. 499-504, 2004.

SHOEMAKER, H. E., E. O. MCLEAN, P. F. PRATT. Buffer methods for determining lime requirement of soils with appreciable amounts of extractable aluminum. Soil Science Society of American. v. 25, p. 274-277, 1961. http://dx.doi.org/10.2136/sssaj1961.03615995002500040014x

SCHUCH, L. O. B.; PESKE, S. T. Aperfeiçoando o processo de semeadura. Revista SEED News, v. 12, n. 6, p. 22-27, 2008.

SCHUCH, L. O. B.; NEDEL, J. L.; ASSIS, F. N.; MAIA, M. S. Crescimento em laboratório de plântulas de aveia-preta (Avena Strigosa Schreb.) em função do vigor das sementes. Revista Brasileira de Sementes, Brasília, v. 21, n. 1, p. 229-234, 1999.

SCHULEECK, F. E., YOUNG, H. G. Equidistant com planting. Crops Soils Magazine, Madison, v. 22, n. 6, p. $12-14,1970$. 
URBEN FILHO, G.; SOUZA, P. I. M. Manejo da cultura da soja sob cerrado: época, densidade e profundidade de semeadura. In: ARANTES, N. E.; SOUZA, P. I. M. (Ed.) Cultura da soja nos cerrados. Piracicaba: POTAFOS, 1993, p. 267-298.

VANZOLINI, S.; CARVALHO, N. M. Efeito do vigor de sementes de soja sobre o seu desempenho em campo. Revista Brasileira de Sementes, v. 24, n. 1, p. 33-41, 2002.

ZONTA, E. P.; SILVEIRA, P. S.; ALMEIDA, A. Sistema de Análise Estatística para Microcomputadores SANEST. Pelotas: Instituto de Física e Matemática, UFPEL, 1986.

WALKER, G. K., BLACKSHAW, R. E., DEKKER. Leaf area and competition for light between plant species direct sunlight transmission. Weed Technology, v. 2, n. 2, p. 159-165, 1988. 